\title{
Cystic tumor of the atrioventricular node in a patient with intermittent complete heart block
}

\author{
Vineeta Ojha (1) ${ }^{1}$ Niraj Nirmal Pandey, ${ }^{1}$ Gautam Sharma, ${ }^{2}$ Priya Jagia ${ }^{1}$
}

${ }^{1}$ Department of Cardiovascular Radiology and Endovascular Interventions, All India Institute of Medical Sciences, New Delhi, India

${ }^{2}$ Department of Cardiology, All India Institute of Medical Sciences Cardio-Thoracic Sciences Centre, New Delhi, New Delhi, India

Correspondence to Dr Priya Jagia; drpjagia@yahoo.com

Accepted 11 June 2021

Check for updates

(C) BMJ Publishing Group Limited 2021. No commercial re-use. See rights and permissions. Published by BMJ.

To cite: Ojha V, Pandey NN, Sharma G, et al. BMJ Case Rep 2021;14:e244442. doi:10.1136/bcr-2021244442

\section{DESCRIPTION}

A 55-year-old man presented with occasional shortness of breath and palpitations for the last 6 months. Holter monitoring revealed intermittent complete heart block and junctional escape rhythm. Transthoracic echocardiography was unremarkable. Cardiac MR was performed to look for any scar or any other structural cause for palpitations. It revealed a $1.2 \times 1 \mathrm{~cm}$ nodular lesion at the anterior mitral leaflet-interatrial septal junction. This lesion appeared isointense on $\mathrm{T} 1 \mathrm{~W}$ images, hyperintense on $\mathrm{T} 2 \mathrm{~W}$ images and showed peripheral rim enhancement with a central dark core on late gadolinium enhancement (LGE) images (figure $1 \mathrm{~A}-\mathrm{C}$ ). T2 mapping values were also raised $(65 \mathrm{~ms})$. On high TI (Inversion Time) LGE images, the lesion was relatively bright. Subsequently, CT angiography was also performed for the assessment of coronaries and to look for any calcification within the lesion. CT demonstrated the lesion with an attenuation of $\sim 70 \mathrm{HU}$ (Hounsfield Units) on the non-contrast CT with no significant enhancement observed in the postcontrast scans (figure 1D-F). Coronary arteries were normal.

On the basis of morphological characteristics, the mass was presumed to be benign. Considering the unusual location of the mass, differential diagnosis included benign lesions like hamartoma, fibroma, cystic tumour of the atrioventricular node (CTAVN) and bronchogenic cyst. However, considering the signal characteristics and the location of the mass as well as patient's symptoms, a likely diagnosis of CTAVN was made. Excision of the lesion was suggested; however, the patient did not opt for the same. Subsequently, pacemaker implantation was done and the patient is on the routine follow-up.

CTAVNs are extremely rare congenital lesions located at the base of the interatrial septum. ${ }^{1}$ Because of their location, these masses often cause complete heart block and arrhythmias and may result in sudden cardiac death. These tumours have mostly been diagnosed postmortem with only a few antemortem reports in the literature. ${ }^{2}$ CTAVNs are generally small and the patients may remain asymptomatic or may present with palpitations, dizziness and dyspnoea. They may have variable signal intensity on CT as well as MRI depending on the composition of the microcysts and the amount of fibrous component. Fiset et al described a similar case of a 51-year-old woman with third-degree atrioventricular nodal block and
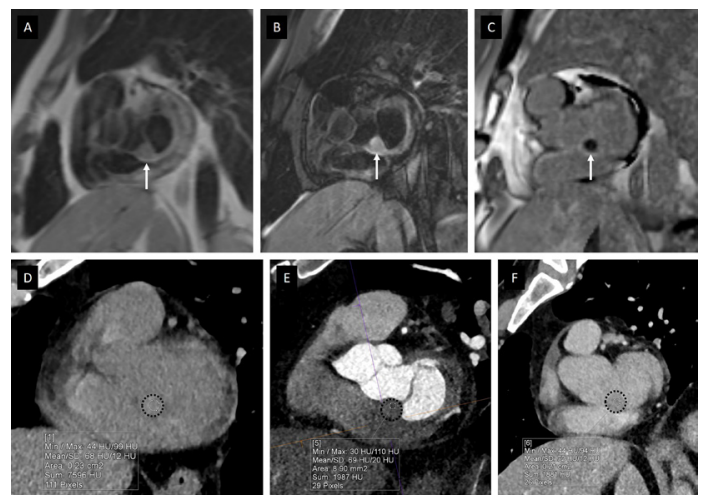

Figure 1 T1-weighted image (A), T2-weighted image (B) and delayed post gadolinium image (C) in the short axis view demonstrate a $1.2 \times 1 \mathrm{~cm}$ nodular lesion (indicated by white arrow) at the anterior mitral leaflet-interatrial septal junction appearing isointense on T1-weighted images, hyperintense on T2-weighted images and showed peripheral rim enhancement with a central dark core on delayed post gadolinium image. Non-contrast CT image (D) and CT angiography images in the arterial phase (E) and delayed phase (F) depict high attenuation (approximately 70 Hounsfield Units (HU)) of the lesion (indicated by black dotted circle) with no significant postcontrast enhancement in the arterial or delayed phase.

\section{Learning points}

A mass at the base of the interatrial septum should alert the clinicians and radiologists to the possibility of cystic tumour of the atrioventricular node.

- Because of their location, these masses often cause complete heart block and arrhythmias and may result in sudden cardiac death.

junctional rhythm. Echocardiography revealed an echogenic mass at the same location as in our case, which showed a soft-tissue attenuation (63 HU) on CT. Although signal intensity on the non-contrast MRI was similar to our case, the lesion showed intense contrast enhancement. ${ }^{1}$ However, absence of postcontrast enhancement has also been reported in other similar cases. ${ }^{3}$ Although rare, a mass at this unusual location (at the base of the interatrial septum) should alert the radiologists to the possibility of this tumour as a differential diagnosis. It must however be emphasised that a tissue diagnosis is necessary 
for a definitive diagnosis of this lesion, which is not present in the current case.

Contributors VO wrote the first draft of the manuscript and conducted the cardiac MRI of the patient. NNP wrote the first draft of the manuscript and conducted the cardiac MRI of the patient. GS revised and approved the manuscript and took part in clinical care of the patient. PJ wrote the first draft, revised and approved the manuscript.

Funding The authors have not declared a specific grant for this research from any funding agency in the public, commercial or not-for-profit sectors.

Competing interests None declared.

Patient consent for publication Obtained.
Provenance and peer review Not commissioned; externally peer reviewed.

\section{ORCID iD}

Vineeta Ojha http://orcid.org/0000-0003-4371-5615

\section{REFERENCES}

1 Fiset S, Butany J, Ing DJ, et al. Multimodality imaging of a rare atrioventricular nodal tumor. Circ Cardiovasc Imaging 2018;11:e008159.

2 Luc JGY, Phan K, Tchantchaleishvili V. Cystic tumor of the atrioventricular node: a review of the literature. J Thorac Dis 2017;9:3313-8.

3 Suzuki K, Matsushita S, Suzuki H, et al. Cystic tumor of the atrioventricular node: computed tomography and magnetic resonance imaging findings. J Thorac Imaging 2014;29:W97-9.

Copyright 2021 BMJ Publishing Group. All rights reserved. For permission to reuse any of this content visit

https://www.bmj.com/company/products-services/rights-and-licensing/permissions/

BMJ Case Report Fellows may re-use this article for personal use and teaching without any further permission.

Become a Fellow of BMJ Case Reports today and you can:

- Submit as many cases as you like

- Enjoy fast sympathetic peer review and rapid publication of accepted articles

- Access all the published articles

Re-use any of the published material for personal use and teaching without further permission

\section{Customer Service}

If you have any further queries about your subscription, please contact our customer services team on +44 (0) 2071111105 or via email at support@bmj.com.

Visit casereports.bmj.com for more articles like this and to become a Fellow 